\title{
Recently agreed changes to the Statutes of the International Committee on Taxonomy of Viruses
}

\author{
M. J. Adams • E. J. Lefkowitz • A. M. Q. King • \\ E. B. Carstens
}

Received: 22 April 2013/ Accepted: 25 April 2013/Published online: 9 July 2013

(C) Springer-Verlag Wien 2013

The International Committee on Taxonomy of Viruses (ICTV; http://www.ictvonline.org/) is a committee of Virology Division of the International Union of Microbiological Societies, and its operation is governed by Statutes agreed with Virology Division. The classification and nomenclature of viruses is then subject to rules formalized into a Code (required by Statute 8.1).

The need for a review of the Statutes and Code became clear during editorial work involved in production of the Ninth ICTV Report [1]. Changes to these documents require the approval of the ICTV Executive Committee (EC) and the full ICTV membership. Changes to the Statutes also require the agreement of Virology Division.

The changes to the Statutes described in this article were discussed and agreed by the ICTV EC over a period of more than two years. Many of these changes are relatively minor adaptations and clarifications. Notification of a ballot was sent via email on 14 January 2013 to the 165 members

M. J. Adams ( $\square)$

Rothamsted Research, Harpenden, Herts AL5 2JQ, UK

e-mail: mike.adams@ rothamsted.ac.uk

\section{E. J. Lefkowitz}

Department of Microbiology, University of Alabama at Birmingham (UAB), BBRB 276, 845 19th St South, Birmingham, AL 35294-2170, USA

e-mail: elliotl@uab.edu

A. M. Q. King

Pirbright Laboratory, The Pirbright Institute, Ash Road,

Pirbright, Surrey GU24 0NF, UK

e-mail: amq.king@ pirbright.ac.uk

\section{E. B. Carstens}

Department of Biomedical and Molecular Sciences, Queen's

University, Kingston, ON K7L 3N6, Canada

e-mail: carstens@queensu.ca of ICTV, namely the ICTV EC Members, Life Members, ICTV Subcommittee Members and ICTV National Representatives. Members were then requested to vote on whether or not to ratify the proposals (voting closed on 14 February 2013). The return rate of votes was approximately $41 \%$, and all proposed changes were accepted unanimously. The proposed changes to the Statutes were then submitted to Virology Division and were approved unanimously by the Advisory Board and Executive Committee on 19 April 2013.

In this article, we present the new version of the Statutes, highlighted in bold to show those parts that have recently been changed. Those changes are then explained in the sections that follow.

The changes to the Code are the subject of a separate article [2].

Complete ICTV Statutes (March 2013)

\section{Article 1}

\section{Official name}

1.1 The official name is the International Committee on Taxonomy of Viruses (ICTV).

\section{Article 2}

\section{Status}

2.1 The ICTV is a Committee of the Virology Division of the International Union of Microbiology Societies (IUMS).

\section{Article 3}

Objectives

The objects of the Committee shall be for the public benefit and in particular to advance education in the taxonomy of viruses and in furtherance thereof. The objectives are:-

3.1 To develop an internationally agreed taxonomy for viruses. 
3.2 To establish internationally agreed names for virus taxa

3.3 To communicate the decisions reached concerning the classification and nomenclature of viruses to virologists by holding meetings and publishing reports.

3.4 To maintain an Official Index of agreed names of virus taxa.

Article 4

\section{Membership}

4.1 Membership of the ICTV shall be:-
A. President and Vice-President
B. Secretaries
C. Other members of the Executive Committee
D. National Members
E. Life Members
F. Members of six Subcommittees.

4.2 The composition of the ICTV Executive Committee shall be:-

(i) The Officers of ICTV, namely President, Vice-president and the Secretaries.

(ii) The Chairs of the six Executive Committee Subcommittees.

(iii) Eight elected Members.

The six subcommittees shall be given remits to ensure that viruses of all host types and of all genome types are included and that one subcommittee is responsible for virus data

4.3 Election or appointment procedures for positions on ICTV and its Executive Committee

A. President and Vice-President shall be nominated and seconded by any members of the ICTV and elected at a plenary meeting of the full ICTV membership. They shall be elected for a term of three years and may not serve for more than two consecutive terms of three years.

B. Two Secretaries shall be nominated by the Executive Committee and elected at a plenary meeting of the full ICTV membership. The Secretaries shall be elected for a term of six years and may be re-elected.

C. The Chairs of the Subcommittees shall be elected by the Executive Committee, normally at an interim meeting preceding a Plenary Meeting of the full ICTV membership. Nominations shall be made to the President at least one week before the election and must be accompanied by indications from each of the nominees that they are willing to serve. The term of office shall be for three years and may not exceed two consecutive terms of three years each.

D. No person shall serve on the Executive Committee for more than four successive complete terms other than as Officers subject to the limitations set out in 4.3.A and 4.3.B.
E. Nominees for each vacant Elected Member seat shall be proposed to an ICTV Plenary Meeting by a Nominations Subcommittee comprising the President, Vice-President, both Secretaries, and the Chairs of the Subcommittees. The Nominations Subcommittee will be chaired by the President and a quorum will consist of 5 members. The Nominations Subcommittee will seek to ensure the widest possible ranges of virological expertise and geographical representation on the EC.

In addition, nominations for an Elected Member vacant seat may be submitted to the Nominations Subcommittee by any virologist and will be allowed up to 2 days prior to the Plenary Meeting at which elections will be held. All nominations must be accompanied by a brief biographical sketch and an indication that the nominee is willing to stand for election.

Elected Members shall be nominated, seconded, and elected at a Plenary Meeting of the ICTV for a term of three years and may not serve for more than two consecutive terms of three years each. Generally, three or four of the eight elected. Members shall be replaced every three years.

F. National Members shall be nominated by Member Societies of the Virology Division of the IUMS. Societies belonging to the IUMS are considered to be Member Societies of the Division if they have members actively interested in virology. Wherever practicable, each country shall be represented by at least one National Member and no country shall be represented by more than five National Members. Nominations of virologists as National Members shall not require approval by the ICTV. However, it is the responsibility of a Member Society to inform one of the ICTV Secretaries in writing of the selection of their National Member before the start of the Plenary Meeting at which that National Member is to participate. National members of the ICTV shall be appointed for 3-year terms soon after each ICV. There is no limit to the number of terms that a National Member may serve but their appointment will be formally reviewed by the appointing National Society every three years.

G. Life Members shall be nominated by the Executive Committee, normally in recognition of outstanding services to virus taxonomy. Currently serving members of the Executive Committee and virologists within 6 months of their retirement from the Executive Committee will not be eligible for election. Life members shall be elected by the full ICTV.

H. Virologists shall be appointed to Subcommittees by the Chairs of the Subcommittees and the appointments will not require approval by the ICTV EC. The EC has the authority to appoint virologists to fill EC positions that are vacant because of resignation or some failure in the normal channels of appointment (4.3 A, B, C, 
E). Such an interim appointment ends at the Plenary Session following their appointment and time spent in such a role does not count towards formal service on the EC as defined by Statute 4.3 D.

\subsection{EC Finance Sub-Committee}

The Finance Subcommittee will consist of the Officers of ICTV. The Subcommittee will appoint a member of the Executive Committee to act as Treasurer of the ICTV. The Treasurer will handle any funds that may be allocated to the ICTV by the Virology Division of the IUMS or other sources.

\subsection{Study Groups}

Study Groups shall be formed by Subcommittee Chairs to examine the classification and nomenclature of particular groups of viruses. A Chair of a Study Group shall be appointed by the Chair of the appropriate Subcommittee and shall be a member of that Subcommittee ex officio.

Chairs of Study Groups shall appoint the members of their Study Groups. Members of Study Groups, other than Chairs, shall not be members of the ICTV, but their names shall be published by the ICTV to recognize their valuable contribution to the taxonomy of viruses. Study Group Chairs and Study Group members will normally be appointed immediately after an ICTV Plenary Session and will serve until the following Plenary Session, which is normally a period of three years. Except in unusual circumstances, the term of office of Study Group Chairs will be limited to two consecutive periods of three years.

\section{Article 5}

\section{Meetings}

5.1 Plenary meetings of the full ICTV membership shall be held in conjunction with the International Congresses of Virology. Meetings of the ICTV Executive Committee shall be held in conjunction with the International Congresses of Virology as well as at least once between International Congresses.

\section{Article 6}

\section{Taxonomic Proposals}

6.1 Taxonomic proposals may be initiated by an individual member of the ICTV, by a Study Group or by a Subcommittee member. In addition, any virologist may submit a taxonomic proposal or suggestion to the appropriate ICTV Subcommittee Chair following the procedures described below.

Proposals will be sent to the Chair of the appropriate Subcommittee for consideration by that Subcommittee and/ or its Study Groups. Proposals will also be sent for consideration to all Study Groups and Subcommittees whose interests might be affected by the taxonomic or nomenclatural changes proposed. Taxonomic proposals approved by any Subcommittee, usually in consultation with a Study
Group, shall be submitted to the Executive Committee by the Subcommittee Chair. Proposals approved by the Executive Committee shall be presented for ratification to the full ICTV membership by publication on an ICTV web site ${ }^{1}$ followed by a ballot.

Article 7

\section{Voting}

7.1 Decisions will be made by a simple majority of either those eligible to vote and present at a meeting or that reply to a call for a vote within 1 month of a proposition being circulated. A quorum for the ICTV Plenary Session decisions will consist of the President or Vice-President together with 15 voting members. In the event of a tied vote the proposal will not be approved.

7.2 The members of the full ICTV who are entitled to vote are the Members of the EC, members of Subcommittees, the National Members and the Life Members. No member may vote more than once on any particular proposal.

7.3 Proposals for changes to taxonomy, nomenclature or the ICTV constitution will be voted on in two stages: (1) the EC will vote either at a meeting or by circulation of a Ballot if a proposal should be presented to the ICTV for a decision, and (2) the ICTV will decide either at a Plenary meeting or by circulation of a Ballot. Decisions of the EC concerned with changes to taxonomy, nomenclature or the constitution will be by simple majority of members of the EC voting. The quorum shall be the President or VicePresident together with 1 Secretary and 7 members of the EC. Only EC members are entitled to vote on such matters.

7.4 Matters of EC business not directly concerned with changes to taxonomy, nomenclature or the constitution may be decided by consensus under the President's chairmanship. Any EC member may call for a vote on such matters.

Article 8

The Code of Virus Nomenclature

8.1 Classification and nomenclature of viruses and related agents will be subject to Rules formalised into a Code. The Code, and substantive modifications to it, are subject to the approval of ICTV Executive Committee and ICTV as under Article 7.

Article 9

Duties of Officers

9.1 Duties of the President shall be:

A. To preside at meetings of the Executive Committee and plenary meetings of the full ICTV membership.

\footnotetext{
1 The current web site used for posting taxonomic proposals is: http://talk.ictvonline.org/files/proposals/m/mediagallery/default.aspx.
} 
B. To prepare with the Secretaries the agendas for meetings of the Executive Committee and the plenary meetings of the full ICTV membership.

C. To act as or appoint an editor-in-chief for ICTV Reports.

\subsection{Duties of the Vice-President shall be:}

A. To carry out the duties of the President in the absence of the President.

B. To attend meetings of the Executive Committee and plenary meetings of the ICTV.

9.3 Duties of the Secretaries shall be:

A. To attend meetings of the Executive Committee and plenary meetings of the ICTV.

B. To prepare with the President the agendas for meetings of the EC and the plenary meetings of the ICTV.

C. To prepare the Minutes of meetings of the Executive Committee and plenary meetings of the ICTV and ensure their timely publication on an ICTV web site.

D. To keep an up-to-date record of ICTV membership.

9.4 Duties of the Subcommittee Chairs shall be:

A. To attend meetings of the Executive Committee.

B. To appoint members of the Subcommittee.

C. To appoint Study Group Chairs.

D. To organize the Subcommittee and Study Groups to study taxonomic problems and to bring forward proposals.

E. To present taxonomic proposals to the Executive Committee for voting.

F. To co-ordinate the preparation of up-dates of the ICTV Reports.

G. To report to the plenary meetings of ICTV on taxonomic changes since the preceding plenary meeting.

Article 10

Publications

10.1 Changes to taxonomy, nomenclature or the International Code approved by ICTV will be communicated to the virological community by publication in rapid short form, for example in Virology Division News, and as part of the published Reports of ICTV.

10.2 Whenever feasible, taxonomic information will be published in a database form under the guidance of the Virus Data Subcommittee.

10.3 No publication of the ICTV shall bear any indication of sponsorship by a commercial agency, or institution connected in any way with a commercial company, except as an acceptable acknowledgement of financial assistance, unless approved by the Executive Committee on a case-by-case basis.
10.4 Publications may bear the name of the ICTV only if all the material contained has been authorized, prepared, or edited by the ICTV, or a committee or subcommittee of the ICTV.

10.5 Publications containing translations of ICTVapproved material may only bear the name of ICTV if they are approved by the ICTV Executive Committee.

Article 11

\section{ICTV Statutes}

11.1 The Statutes of the ICTV, and any subsequent changes, shall be approved by votes of the ICTV EC and the full ICTV membership as under Statute 7 and then approved by the Virology Division of the IUMS.

Article 12

Disposition of Funds

12.1 In the event of dissolution of the ICTV, any remaining funds shall be turned back to the SecretaryTreasurer of the Virology Division of the IUMS.

12.2 Any surplus assets/funds must be used for the charitable purposes set out at Article 3 of this constitution or for purposes that are charitable within the context of Section 505 of the Income and Corporation Taxes Act 1988 (or statutory re-enactment thereof).

Article 13

\section{Legal Seat}

13.1 The ICTV shall have its legal seat where the office of the President is located.

Changes made in 2013

Article 3 (Objectives)

Previous wording:

3.2 To establish internationally agreed names for virus taxa, virus species and subviral agents.

3.4 To maintain an Official Index of virus names.

New wording:

3.2 To establish internationally agreed names for virus taxa.

3.4 To maintain an Official Index of agreed names of virus taxa.

Explanation:

It is not clear why the original statute made a distinction between virus taxa and virus species or what was meant in 3.2 by the nonspecific term subviral agents. The Code provides for the classification of viroids in a way similar to viruses (Code 3.35 and 3.36), includes retrotransposons within virus classification (3.37) but excludes satellites and prions (3.38). As this is all made clear in the Code, this Statute has been simplified. Statute 3.4 was changed because 'virus names' nowadays usually refers to names not regulated by ICTV but which are allocated to species (and higher taxa).

Article 4 (Membership)

Previous wording: 
4.1 Membership of the ICTV shall be:-

F. Members of the Prokaryote Virus, Fungal Virus, Invertebrate Virus, Plant Virus, Vertebrate Virus, and Virus Data Subcommittees.

4.2 The composition of the ICTV Executive Committee shall be:-

(ii) The Chairs of the Executive Committee Subcommittees, namely one each for the Subcommittees on viruses of prokaryotes (including Archaea), fungi (including algae), invertebrates, plants and vertebrates, and one for the Virus Data Subcommittee

(iii) Eight elected Members.

New wording:

4.1 Membership of the ICTV shall be:-

$\ldots$

F. Members of six Subcommittees.

4.2 The composition of the ICTV Executive Committee shall be:-

(ii) The Chairs of the six Executive Committee Subcommittees

(iii) Eight elected Members.

The six subcommittees shall be given remits to ensure that viruses of all host types and of all genome types are included and that one subcommittee is responsible for virus data.

Explanation:

There seems no reason to specify in the Statutes the precise remits of each subcommittee. Until now these have been arranged by host type but these traditional divisions of virology are breaking down with the increasing discovery of viruses in a range of hosts and from unknown hosts in environmental samples. The changes provide the Executive Committee with the flexibility to organize some Subcommittees in different ways (e.g. by genome type), perhaps even on a temporary basis, to be able to respond to changing challenges in taxonomy without the need to change the Statutes on each occasion. Six subcommittees are specified to maintain the balance between the numbers of appointed and elected members of the Executive Committee.

Previous wording:

4.4 EC Finance Sub-Committee

The Finance Sub-Committee will consist of the Officers of ICTV.

New wording:

4.4 EC Finance Sub-Committee

The Finance Sub-Committee will consist of the Officers of ICTV. The Subcommittee will appoint a member of the Executive Committee to act as Treasurer of the ICTV. The Treasurer will handle any funds that may be allocated to the ICTV by the Virology Division of the IUMS or other sources.

Explanation:

The Officers are the President, Vice-President and the two Secretaries (Statute 4.2). Most recently, the role of Treasurer has been a duty of the Vice-President (see Statute 9.2), but this has not always proved a convenient arrangement. Amongst other factors, the difficulty of moving the ICTV bank account to a different country needs to be recognized. The change allows some flexibility in the arrangements.

Previous wording:

4.5 Study Groups

... Members of Study Groups, other than Chairs, shall not be members of the ICTV, but their names shall be published in the minutes and reports of the ICTV to recognize their valuable contribution to the taxonomy of viruses ...

New wording:

4.5 Study Groups

... Members of Study Groups, other than Chairs, shall not be members of the ICTV, but their names shall be published by the ICTV to recognize their valuable contribution to the taxonomy of viruses ...

Explanation:

Publishing a full list of names of Study Group members in the Minutes is not practicable and the ICTV Reports are likely to become an online publication with regular updates. Study Group members are currently listed on an ICTV web site (http://www.ictvonline.org/studygroups.asp), and this appears to be the best procedure for the foreseeable future.

\section{Article 6 (Taxonomic Proposals)}

Previous wording:

6.1 ... Proposals approved by the Executive Committee shall be presented for ratification to the full ICTV membership either at the subsequent Plenary meeting or by circulation of proposals by mail followed by a Ballot.

Separate proposals shall be required (1) to establish a new taxon, (2) to name a taxon, (3) to designate the type species of a genus and (4) to establish a list of members of a taxon.

New wording:

... Proposals approved by the Executive Committee shall be presented for ratification to the full ICTV membership by publication on an ICTV web site followed by a ballot.

Explanation:

This firstly regularizes what has become the practice for recent ratification votes using modern technology. The final sentence has now been removed. It concerns the detailed procedure for making proposals and is more logically 
handled by the Code (see comment to rule 3.7). Additionally, part (4) is at best a confusing statement.

Article 9 (Duties of Officers)

Previous wording:

9.1 Duties of the President shall be:

C. To act as editor-in-chief for ICTV Reports.

New wording:

9.1 Duties of the President shall be:

C. To act as or appoint an editor-in-chief for ICTV Reports.

Explanation:

This reflects recent practice and ensures that the President retains overall responsibility for any Report produced.

Previous wording:

9.2 Duties of the Vice-President shall be:

C. To act as Treasurer of the ICTV. To handle any funds that may be allocated to the ICTV by the Virology Division of the IUMS or other sources.

New wording:

[This sentence has been removed]

Explanation:

It has not proved possible to link the function of Treasurer to that of Vice-President. An alternative way to appoint the Treasurer is contained in the proposed change to Statute 4.4.

Previous wording:

9.3 Duties of the Secretaries shall be:

...

C. To prepare the Minutes of meetings of the Executive Committee and plenary meetings of the ICTV and circulate them to all ICTV members.

New wording:

9.3 Duties of the Secretaries shall be:

...

C. To prepare the Minutes of meetings of the Executive Committee and plenary meetings of the ICTV and ensure their timely publication on an ICTV web site.

Explanation:

Circulation to all ICTV members is cumbersome and there is a much wider community of virologists who have an interest in the decisions of the Executive Committee and plenary meetings. The agreed minutes will in future be freely available via the internet.

Previous wording:

9.4 Duties of the Subcommittee Chairs shall be:
G. To report to the plenary meetings of ICTV on taxonomic changes since the preceding ICTV Report and to present any current proposals for further change.

New wording:

9.4 Duties of the Subcommittee Chairs shall be:

G. To report to the plenary meetings of ICTV on taxonomic changes since the preceding plenary meeting.

Explanation:

The original statute reflects the earlier practice of voting on taxonomic proposals at a plenary meeting and then publishing a Report including the decisions recently made. This is no longer a practical way of conducting ICTV business; in addition, the latest published Report is expected to be updated rather than replaced.

\section{Article 10 (Publications)}

Previous wording:

10.1 Changes to taxonomy, nomenclature or the International Code approved by ICTV will be communicated to the virological community by publication in rapid short form, for example in Virology Division News, and as part of the formal triennial Report of ICTV.

New wording:

10.1 Changes to taxonomy, nomenclature or the International Code approved by ICTV will be communicated to the virological community by publication in rapid short form, for example in Virology Division News, and as part of the published Reports of ICTV.

Explanation:

This is a change to be consistent with the current publishing plan for the ICTV Reports.

\section{New Article 13 (Legal Seat)}

New wording:

13.1 The ICTV shall have its legal seat where the office of the President is located.

Explanation:

A legal seat for the ICTV is expected when dealing with banks and other official bodies. This Statute is similar to the one in the Statutes of IUMS Virology Division.

\section{References}

1. King AMQ, Adams MJ, Carstens EB, Lefkowitz EJ (2011) Virus taxonomy. Ninth report of the International Committee on Taxonomy of Viruses. Elsevier Academic Press, London

2. Adams MJ, Lefkowitz EJ, King AMQ, Carstens EB (2013) Recently agreed changes to the International Code of Virus Classification and Nomenclature. Arch Virol (in press) 